\title{
4. ストレスと睡眠関連ブラキシズム
}

\author{
馬場一美 \\ 東京医科歯科大学大学院医歯学総合研究科摄食機能構築学
}

睡眠関連ブラキシズム (以下ブラキシズム) は咀嚼筋活動を主体とした睡眠中に行われるパラファン クション (異常機能) である. パラファンクションとは, オルソファンクション (正常機能), ティス ファンクション（機能障害）に対応するものであり，このように呼ばれる理由は，咀鲅，嚥下，発音な どの活動と比較して機能的目的を全く持っていないように見えるからである. パラファンクションは必 ずしも組織に後遺障害をもたらすわけではないが, その強度や頻度が生体の耐性を超えて行われると組 織に障害を来たす。

臨床においては問診と臨床診查によりブラキシズムの診断が行われているが, 睡眠中の現象であるブ ラキシスムを正確に予測することは容易ではない.ブラキシズムの実際の測定は睡眠ポリグラフの備わ った睡眠実験室や，携帯型の特殊な装置を用いて家庭環境で行われているが，これらは主に研究目的で 行われる. 過去の研究により,ブラキシズムには覚醒時の最大咬みしめ時以上の大きさの筇活動を伴う 例や，300 秒間も持続する例が報告されており，このような強く長時間持続するブラキシズムは, 歯, 補綴物, 顎関節, 咀嚼筋のすべてに対して組織障害や疼痛障害等の為害作用を及ぼす可能性がある.こ れらの関係は臨床家に広く受け入れられているにもかかわらず残念ながら裏付けとなるエビデンスは 十分ではない。

ブラキシズムの原因はストレスや薬物など様々な因子が関連していると考えられている.特にストレ スはブラキシズムの原因として長く注目されてきた. 情動ストレスの上昇は, 筋紡鍾のガンマ遠心性二 ユーロンの活動や交感神経系の活動を亢進することが報告されており, 筋長に対する感度の上昇は筋緊 張を充進させるため, 間接的にブラキシズムが引き起こすことを示唆している. また, ブラキシズムの 日間差が有意であるとの報告もストレス・ブラキシズム関係を支持する根拠となりえる. 事実, 日中の ストレス・イベントと睡眠中に記録された咀嚼筋活動との有意な関係を報告した研究もみられるが, 両 者の関係が系統立てて検証されておらず，なおかつ，ある特定の患者群においてのみ関連性が認められ ている.

ここで, 注意すべき点はブラキシズムの原因として捉えられているストレス,さらにその結果として 捉えられている疼痛障害のいずれもが睡眠構造, あるいは睡眠の質に影響を及ぼすということである。 それゆえストレス・ブラキシズム関係を単純な因果関係として捉えることには限界がある，つまり，こ の関係を理解するためには, バックグラウンドにある睡眠を生理的、社会的、医学的に理解することが 必須であり，ストレス・ブラキシズム関係についての研究も睡眠医学により踏み込んで行われることが 望まれる，今回はストレス・ブラキシズム関係についての文献的検証を通して, 歯科臨床と睡眠との関 連性について言及したい. 